Journal of Contemporary Educational Research

Research Article

\title{
Research on the Teaching Reform of Women's Clothing Design Course under the Background of Cultural and Creative Industry Development
}

Yi Fang

Jilin Engineering Normal University, Changchun 130052, China

\begin{abstract}
With the rapid development of China's cultural and creative industries, the influence of cultural and creative ideas in fashion design is increasing, and art talents with innovative ability have become hot objects in the society. As the cradle of fashion design talents training and output, colleges and universities in our country shoulder the important task of training fashion design talents in the new period. In the current clothing design curriculum reform, school enterprise cooperation and collaborative innovation have become an important development direction. Under this background, this paper analyzes the teaching reform path of women's clothing design course in Colleges and universities.
\end{abstract}

Key words: Creative industry; Women's wear design; Teaching reform; Route

Publication date: October, 2020

Publication online: 31 October, 2020

*Corresponding author: Yi Fang, fangyi202011@126. com

\section{Cultural and creative brand development trend and talent demand}

In July 2019, the National Bureau of statistics released the big data of "national cultural and related industry enterprises above designated scale in the first half of 2019 ". According to the survey of nearly 56000 related enterprises in China, the above enterprises achieved revenue of 4055.2 billion yuan in the first half of 2019, an increase of $7.9 \%$ over the same period of last year. Among them, in the first half of the year, the revenue of "content creation production", a major category of Arts and crafts manufacturing, was 986 billion yuan, an in- crease of $9.8 \%$ over the same period last year. In recent years, under the leadership of cultural and creative industries in the Forbidden City, the category of "creative design services", where cultural and creative industries are located, has a revenue of 542.4 billion yuan in the first half of the year, an increase of $12.4 \%$ over the same period last year.

While maintaining rapid development, China's cultural and creative industries are further showing the trend of "cultural and creative +" comprehensive integration and development: cultural and creative industries embrace new technologies such as mobile Internet, big data, Internet of things, artificial intelligence, etc., and new technologies not only bring vitality to traditional cultural industries. With the continuous progress and deep integration of cultural and creative industries, creative related majors such as fashion design, fine arts, animation, film and television have also developed by leaps and bounds. In addition, people are becoming more and more aesthetic, which promotes the creative industry to a higher level of development. Under the background of "cross-border talents and creative talents", the demand for talents and creative talents has become more and more important.

Table 1. Operating income of cultural and related industry enterprises above Designated Size in the first half of 2019

\begin{tabular}{lccc}
\hline & $\begin{array}{c}\text { Absolute } \\
\text { amount } \\
(100 \\
\text { million })\end{array}$ & $\begin{array}{l}\text { Increase over } \\
\text { the same period } \\
\text { of last year }\end{array}$ & $\begin{array}{c}\text { Proportion } \\
(\%)\end{array}$ \\
\hline Total & $\mathbf{4 0 5 5 2}$ & $\mathbf{7 . 9}$ & $\mathbf{1 0 0 . 0}$
\end{tabular}

By industry category

News information service

2997

25.1

7.4 


\begin{tabular}{|c|c|c|c|}
\hline $\begin{array}{l}\text { Content creation and } \\
\text { production }\end{array}$ & 9860 & 9.8 & 24.3 \\
\hline Creative design services & 5424 & 12.4 & 13.4 \\
\hline $\begin{array}{l}\text { Cultural communication } \\
\text { channels }\end{array}$ & 5229 & 8.2 & 12.9 \\
\hline $\begin{array}{l}\text { Cultural investment and } \\
\text { operation }\end{array}$ & 198 & 10.2 & 0.5 \\
\hline $\begin{array}{l}\text { Cultural entertainment and } \\
\text { leisure services }\end{array}$ & 682 & 4.2 & 1.7 \\
\hline $\begin{array}{l}\text { Cultural auxiliary } \\
\text { production and intermediary } \\
\text { service }\end{array}$ & 6463 & -2.0 & 15.9 \\
\hline $\begin{array}{l}\text { Cultural equipment } \\
\text { production }\end{array}$ & 2586 & 5.3 & 6.4 \\
\hline $\begin{array}{l}\text { Cultural consumption } \\
\text { terminal production }\end{array}$ & 7112 & 7.0 & 17.5 \\
\hline \multicolumn{4}{|l|}{ By industry type } \\
\hline $\begin{array}{l}\text { Cultural manufacturing } \\
\text { industry }\end{array}$ & 17012 & 4.4 & 42.0 \\
\hline $\begin{array}{l}\text { Cultural wholesale and } \\
\text { retail }\end{array}$ & 6934 & 5.5 & 17.1 \\
\hline Cultural service industry & 16606 & 13.0 & 40.9 \\
\hline \multicolumn{4}{|l|}{ By field } \\
\hline Core areas of culture & 24391 & 11.5 & 60.1 \\
\hline Culture related fields & 16161 & 3.0 & 39.9 \\
\hline \multicolumn{4}{|l|}{ By region } \\
\hline Eastern Region & 30586 & 6.8 & 75.4 \\
\hline Central Region & 5771 & 10.2 & 14.2 \\
\hline Western Region & 3806 & 15.6 & 9.4 \\
\hline Northeast Region & 389 & -0.2 & 1. \\
\hline
\end{tabular}

2 The teaching reform direction of women's clothing design course under the background of cultural and creative industry development

In January 2019, the State Council issued the national vocational education reform implementation plan to support the integration of industry and education from the policy level, and put forward specific indicators for vocational education reform - by 2022, tens of thousands of industry education integration enterprises will be cultivated, and 300 high-level professional training bases with radiation leading role will be promoted.

Collaborative innovation refers to the innovation process of breaking through barriers among innovation subjects, effectively gathering innovation resources and elements, fully releasing the vitality of each other's innovative elements such as talents, capital, information and technology, and realizing deep cooperation. School enterprise cooperation is an important way of collaborative innovation.
According to the author's analysis of the development of school enterprise collaboration, the collaborative innovation between colleges and enterprises has made remarkable achievements in the natural field, but it is less applied in Humanities and Social Sciences, and it is relatively backward in the application of fashion design. At present, the defects in the training of fashion design professionals in Colleges and universities in China include the following aspects. First of all, the service awareness of colleges and universities is not strong, and the social needs are not fully considered in the training of talents, which leads to unclear goals and positioning, and can not respond to the requirements of economic transformation and development. Secondly, some school enterprise cooperation stops at the formal level, which can not achieve collaborative training of talents, and the supporting security and evaluation mechanism is not perfect. Finally, colleges and universities in the enrollment of art and design related professional students, resulting in a large number of students, enterprises can not afford and digest, the scale of school enterprise cooperation is relatively small.

\section{Teaching reform path of women's clothing design course under the background of cultural and creative industry development}

\subsection{The reform of scientific and technological teaching means}

In the teaching of women's clothing design course, the combination of multimedia demonstration, clothing CAD drawing and blackboard writing is adopted in the teaching of structural design courses. The application of multimedia can show the static and dynamic teaching contents more vividly, vividly, quickly and accurately, and improve the efficiency of class. However, the interaction between students and teachers is not active, and teachers can not master the effect of students' preview before class and review after class. With the development of computer and network information technology, the application of digital technology has become an important content of professional teaching reform in Colleges and universities. At present, MOOC, micro class, online course, teaching app and other teaching methods are widely used in professional teaching. With the help of APP platform, we can upload teaching materials, videos and other contents related to the course, which is convenient for students to preview 
before class and review after class, and broaden the knowledge of structural design outside the textbook; at the same time, it can complete the teaching links of students' sign in, classroom interaction, group discussion, assignment and submission; it also facilitates the interaction between students and teachers, and students' problems can be solved in time. At present, this course is an excellent course under construction in our school. Using the cloud platform of "excellent college" for online course construction, teaching materials can be uploaded at any time without class restrictions, which is convenient for garment majors of different grades to learn at any time. In addition, virtual reality and augmented reality technology is one of the important means of the teaching reform of clothing technology course. It can realize the highprecision camera and real-time multi screen play of the teacher's demonstration process, which provides a more convenient teaching space for teaching, so that each student can directly see the teacher's demonstration process and operation steps. The system also provides on-demand and playback functions to improve students' learning autonomy and enthusiasm.

\subsection{On campus tutor + off campus tutor building professional practice team}

Only when the teaching staff becomes strong, refined and high, can the innovation of practical teaching system be truly implemented, which is also a factor affecting the cultivation of innovative design talents. Women's clothing design major should strengthen the development of teaching staff from a long-term perspective. First of all, we should vigorously "bring in", quickly introduce a group of industry experts through the humanized and diversified mode, and improve the professional level of the whole practice team in the fastest time. Secondly, we should vigorously "go out" and encourage teachers to participate in training, further study, investigation and exchange, so as to improve their practical guidance level. The mechanism of "bringing in" and "going out" should be combined to ensure the stable cultivation of practical teaching ability of a group of discipline leaders and backbone teachers. Strengthen the cooperation with garment enterprises and improve the assessment level of "double qualification". In addition, we should strengthen the construction of practical teaching guarantee system and improve the corresponding systems and standards

\subsection{Cultivate "cultural and creative thinking" of women's clothing design talents}

In the future "cultural and creative +" era, having "cultural and creative thinking" is more conducive to promoting the linkage between industries, which will undoubtedly play a positive role in promoting the cultivation of cultural and creative talents in China in the future. The practical experience of cultural and creative industry can be refined into "cultural and creative thinking", and applied in the field of personnel training. For example, the school of culture and innovation of Shanghai Jiaotong University is cooperating with enterprises to enable students to form an interdisciplinary and interdisciplinary team of "cultural innovation + X", so as to cultivate students' cross-border ability of cultural and creative, and solve the problems faced by enterprises. This project summarizes the methodology of digital culture and innovation in improving experience and sense of identity, and sets up industry practice and innovation courses such as cultural innovation + film and television entertainment, cultural and creative + sports, cultural and creative + cultural tourism, cultural and creative + education. Through the form of methodology + industry practice, it helps students apply cultural and creative thinking in various industries and finally become compound talents.

\section{References}

[1] Zhao YM, Yang XD, Li J. Research on Teaching Reform of Garment Cognition Practice[J]. Shandong Textile Economy, 2020(4): 48-50

[2] Zeng ZW, Shen L, Ren XF. Research on the Intelligent Fashion Design Pattern Based on Female Security[J]. Journal of Clothing Research, 2018, 3(5): 395-399.

[3] Hou KH. Reforming the Course of the Apparel Structure Design of the"Dual-type"Education[J]. Journal of Huizhou University, 2019, 39(6): 89-92. 